financial, as well as scientific, drawbacks in the final product. Future volumes in this series will be awaited with interest.

Michael Clemens

\title{
Comprehensive virology 15. Virus-host interactions. Immunity to viruses
}

Edited by H. Fraenkel-Conrat and R. R. Wagner. New York: Plenum Press. Pp. xv and 293. US\$29.50.

This is the latest addition to a series of books on virology, the previous ones having dealt with molecular and biological properties. There are five chapters, beginning with a description, by M. B. A. Oldstone, of general immune responses and specifically immune tolerance. He out lines his own work, and that of others, with lymphocytic choriomeningitis virus and presents evidence that the state of tolerance induced in immune incompetent neonates by direct inoculation of the virus or its vertical transmission from infected mothers is not absolute, because specific antibodies, within immune complexes, and even a T-cell response can be found. The second chapter, by $B$. Mandel, tries to untangle the mysteries of the interaction of viruses with neutralising antibodies. He discusses the methods of measuring neutralising antibody and the kinetics of neutralisation, and attempts to throw some light on the mechanism. This is a comprehensive treatise on neutralisation, with the historical background, and includes recent hypotheses on how infectious virus is neutralised. Next is a chapter by N. R. Cooper describing the humoral response with the emphasis on the possible role of complement in combating virus infections. This is a neat, succinct piece of writing that threads its way through the intricacies of the complement system, with references for those who need the finer details. Since the discovery of cytotoxic $T$ cells, researchers have been investigating their role in immunity to virus infections, none more successfully than the author of the chapter on T-cell response, R. M. Zinkernagel. However, this was a slightly disappointing chapter because, unlike the others, he did not introduce us gently to the subject. A short resumé of the major histocompatibility complexes and maps of the HLA system in humans and the $\mathrm{H} 2$ systems in mice would have made easier what for many may be a difficult chapter. The final chapter, on interferon, is by E. De Maeyer and J. De Maeyer-Guignad. It concentrates on type-I (fibroblast) interferon because more is known abouts its structure and induction, than in the case of type II (leucocyte) interferon, and because it may be more important for viral infections, being produced by all tissue cells. This is also a very comprehensive chapter describing research on interferon from the time of its discovery. Interferon is a very topical subject and this chapter shows the failings of books attempting to present up-to-date work. The authors mention that more valid progress would be made in understanding the molecular biology of interferon and its clinical potential if its genetic information could be cloned in bacteria-something actually achieved only recently. Nevertheless, this is a very good chapter, which deals also with the other actions of interferon, including its possible regulatory role in the immune system.

This book highlights the problems of research on host-virus interactions, by experts in the field, and each chapter is accompanied by a large bibliography. It should be useful to postgraduate students and research workers in the fields of virology and immunology.

D. J. MCCANCE

\section{Practical tissue culture applications}

Edited by K. Maramorosch and H. Hirumi. 1979. London and New York: Academic Press. Pp. xiii and 426 . US\$29.50.

This unusual little book is the outcome of a conference held at the International Laboratory for Research on Animal Diseases in Nairobi, Kenya, in August 1978. It is primarily concerned with ways in which tissue culture can be applied in the study and management of tropical parasitic diseases and, with this as a theme, it crosses some of the common disciplinary boundaries and brings together a disparate but related collection of papers. 